Neuro/mages
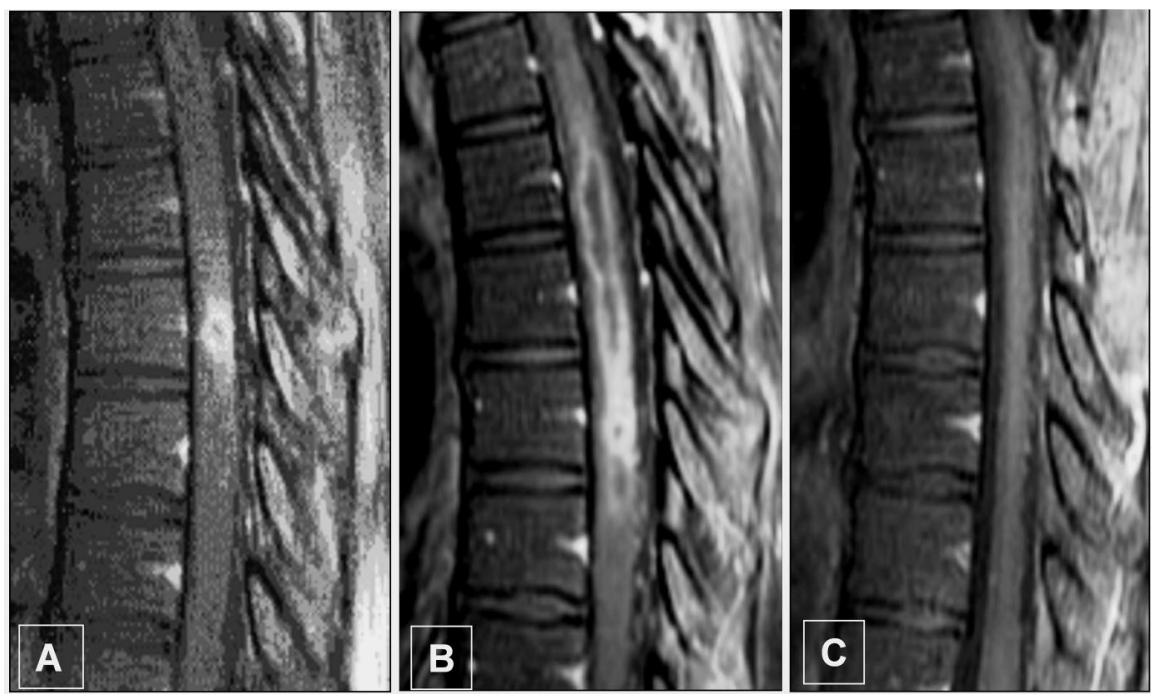

Figure. (A) Sagittal T2-weighted MRI of the thoracic cord (day 1) demonstrates an intramedullary ring enhancing lesion at T8. (B) Sagittal T2 (day 4) showing enlargement of the lesion extending superiorly to T3 and inferiorly to T11. (C) Sagittal T2 image (1 year out) with resolving abnormal signal at T6-T9.

\section{Intramedullary spinal cord abscess in a healthy woman}

A. Applebee, MD; M. Ramundo, MD; B.D. Kirkpatrick, MD; T.J. Fries, $M D$; and $H$. Panitch, $M D$, Burlington, VT

A 47-year-old woman reported burning abdominal discomfort, urinary retention, and leg paresthesias 1 week after dental cleaning. Examination revealed right leg weakness and sensory loss to T10. MRI showed an intramedullary ring-enhancing

Disclosure: The authors report no conflicts of interest.

Address correspondence and reprint requests to Dr. Angela Applebee, 1 South Prospect Street, Burlington, VT 05401; e-mail: angela.applebee@vtmednet.org lesion at T8 (figure, A). By day 7, she was paraplegic with a T3 sensory level. Repeat MRI showed edema from C3 to the conus medullaris, with $\mathrm{C} 7$ to T11 enhancement (figure, B). Urgent abscess drainage was performed. Paraplegia and a T4 sensory level remained despite radiographic resolution (figure, C). Cultures revealed oral flora. Early broad-spectrum antibiotic therapy is indicated when intramedullary spinal cord abscess is suspected. ${ }^{1}$

1. Chan CT, Gold WL. Intramedullary abscess of the spinal cord in the antibiotic era: clinical features, microbial etiologies, trends in pathogenesis, and outcomes. Clin Infect Dis 1998;27:619-626.

See also page 1231 


\section{Neurology}

\section{Intramedullary spinal cord abscess in a healthy woman}

A. Applebee, M. Ramundo, B. D. Kirkpatrick, et al. Neurology 2007;68;1230

DOI 10.1212/01.wnl.0000250231.86932.04

This information is current as of April 9, 2007

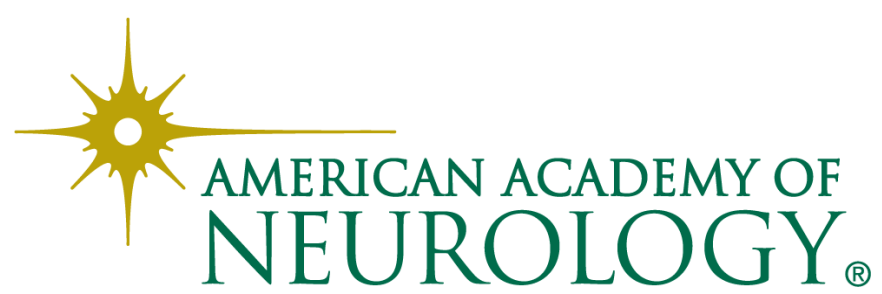




\section{Updated Information \& Services}

\section{Supplementary Material}

\section{References}

\section{Subspecialty Collections}

\section{Errata}

Permissions \& Licensing

\section{Reprints}

including high resolution figures, can be found at: http://n.neurology.org/content/68/15/1230.full

Supplementary material can be found at: http://n.neurology.org/content/suppl/2007/11/08/68.15.1230.DC1

This article cites 1 articles, 0 of which you can access for free at: http://n.neurology.org/content/68/15/1230.full\#ref-list-1

This article, along with others on similar topics, appears in the following collection(s):

\section{Abscess}

http://n.neurology.org/cgi/collection/abscess

All Infections

http://n.neurology.org/cgi/collection/all_infections

\section{Bacterial infections}

http://n.neurology.org/cgi/collection/bacterial_infections

\section{MRI}

http://n.neurology.org/cgi/collection/mri

Spinal cord infection

http://n.neurology.org/cgi/collection/spinal_cord_infection

An erratum has been published regarding this article. Please see next page or:

/content/69/2/225.2.full.pdf

Information about reproducing this article in parts (figures,tables) or in its entirety can be found online at:

http://www.neurology.org/about/about_the_journal\#permissions

Information about ordering reprints can be found online:

http://n.neurology.org/subscribers/advertise

Neurology ${ }^{\circledR}$ is the official journal of the American Academy of Neurology. Published continuously since 1951, it is now a weekly with 48 issues per year. Copyright . All rights reserved. Print ISSN: 0028-3878. Online ISSN: 1526-632X.

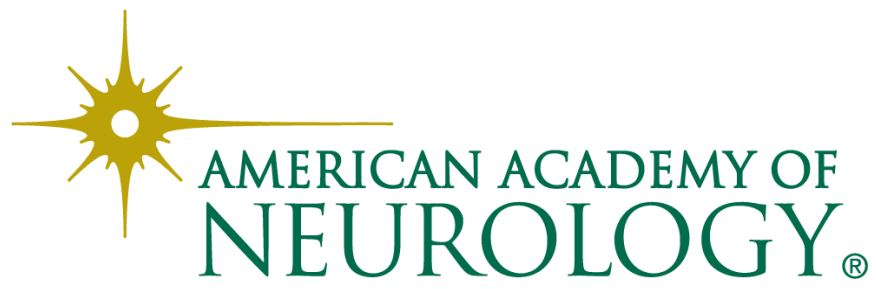


group of cases who were asymptomatic and $\geq 75$ years old. The major factor driving inappropriateness among asymptomatic patients was the degree of comorbid illness burden. Asymptomatic patients $\geq 75$ years old had the same distribution of comorbidity compared with those $<75$ years old ( $p=$ 0.98). While age itself was not a factor in the appropriateness ratings, we found no differences in rates of inappropriate CEA comparing asymptomatic patients who were $\geq 75$ years old to all other patients $(8.2 \%$ vs $8.8 \%, p=0.34)$.

Reclassifying all asymptomatic patients $\geq 75$ years old as having uncertain appropriateness, as Dr. Chaturvedi discusses, would substantially raise the proportion considered uncertain (by shifting many patients out of the appropriate category). The proportion considered inappropriate would not change. Thus, our main finding, that since publication of the RCTs rates of CEA for inappropri- ate reasons fell from $32 \%$ to $8.6 \%$, would not be affected. ${ }^{1}$

Ethan A. Halm, Stanley Tubrim, MD, Mark R. Chassin, MD, MPH, MPP, New York, NY

Disclosure: The authors report no conflicts of interest.

Copyright (C) 2007 by AAN Enterprises, Inc.

1. Halm EA, Tuhrim S, Wang JJ, et al. Has evidence changed practice? Appropriateness of carotid endarterectomy after the clinical trials. Neurology 2007;68:187-194.

2. MRC Asymptomatic Carotid Surgery Trial (ACST) Collaborative Group. Prevention of disabling and fatal strokes by successful carotid endarterectomy in patients without recent neurological symptoms: randomised controlled trial. Lancet 2004;363:1491-1502.

3. Chaturvedi S, Bruno A, Feasby T, et al. Carotid endarterectomy: an evidence-based review. Neurology 2005;65: 794-801.

4. Halm EA, Chassin MR, Tuhrim S, et al. Revisiting the appropriateness and use of carotid endarterectomy. Stroke 2003;34:1464-1472.

\section{CORRECTION}

Paraplegia caused by invasive spinal aspergillosis

In the NeuroImage "Paraplegia caused by invasive spinal aspergillosis" by P.C. Karakousis (Neurology 2007;68:158), the fifth sentence should read as follows: "MRI studies revealed an edematous spinal cord from C5 through the conus with multiple high-signal T2 lesions (figure, A); postgadolinium T1 images (not shown) demonstrated multiple enhancing intramedullary masses.”

The figure legend should read as follows:

Figure. (A) T2 weighted sagittal MRI of the spine 8 months after the onset of paraparesis, indicating multiple intradural, intramedullary masses (arrows); postgadolinium T1 images (not shown) demonstrated contrast enhancement in all lesions. (B) High-power view of spinal cord biopsy, demonstrating fungal hyphae consistent with Aspergillus species. Gomori methenamine silver stain.

The authors regret the error.

\section{CORRECTION}

Intramedullary spinal cord abscess in a healthy woman

In the NeuroImage "Intramedullary spinal cord abscess in a healthy woman" by A. Applebee et al. (Neurology 2007;68: 1230), there is an error describing the images. All three of the images are fat-suppressed T1 postcontrast images. The figure legend should read as follows:

Figure. (A) Sagittal fat-suppressed T1 postcontrast MRI of the thoracic cord (day 1) demonstrates an intramedullary ring enhancing lesion at T8. (B) Sagittal T1 postcontrast (day 4) showing enlargement of the lesion extending superiorly to T3 and inferiorly to T11. (C) Sagittal T1 postcontrast image (1 year out) with resolving abnormal signal at T6-T9.

The authors regret the error. 